\title{
An unusual presentation of Epstein-Barr Virus induced hepatitis in a 15-month-old child
}

\author{
Apresentação incomum de hepatite induzida por Epstein-Barr Virus em criança \\ de 15 meses de idade
}

Gabriel B. Tofani ${ }^{1}$, Tadeu S. Ferreira ${ }^{2}$, Gustavo P. Irffi ${ }^{1}$, Daniela C. S. M. do Valle ${ }^{3}$

\begin{abstract}
Objective: We report an atypical case of hepatitis in an infant that could be helpful to physicians of various specialties, as it demonstrates an atypical clinical and laboratorial manifestation of a disease not so common at that age and that could have gone undiagnosed.

Case Description: A 15-month-old female, immunocompetent patient was referred to the hospital with a 3-day history of fever, vomiting, and diarrhea. The patient presented with alternation between sleepiness and irritation associated with rapid increase in serum liver enzymes levels, but no jaundice. Neurologic evaluation showed no meningeal signs and no encephalic morphological abnormalities were observed in a cranial CT scan. Treatment consisted of symptomatic medication and daily evaluation for signs of hepatic encephalopa- thy or bleeding. A serological panel showed negative IgM but positive IgG reactivity against Cytomega- lovirus (CMV) and IgM and IgG negative immunoreactivity against HAV. She was not tested for Hepatits $B(\mathrm{HBV})$ or Hepatits $\mathrm{C}(\mathrm{HCV})$. Positive immunoreactivity against the Epstein-Barr virus capsid antigen (EBV VCA) IgM and negative reactivity against IgG, indicated a diagnosis of EBV-induced acute hepatitis. The patient was discharged asymptomatic after 11 days, with decreasing serum liver enzymes levels. A 15-day follow up evidenced complete remission of symptoms and normalized laboratory tests.

Comments: Hepatic involvement in infections by Epstein-Barr Virus is common, presenting with moderate and transient increase in liver enzymes. It can go undetected and resolve spontaneously, while clinical manifestations of hepatitis are infrequent. In this report, we present an unusual case of a pediatric patient with hepatitis induced by EBV infection, along with a review of the literature. According to our search, no other EBV-induced hepatitis case reports have been published involving an immunocompetent patient under 2 years of age.
\end{abstract}

Keywords: Herpesvirus 4, Human. Child. Hepatitis.

1. Médico da Saúde da Família. Belo Horizonte.

2. Residente em Cirurgia Geral, Hospital Alberto Cavalcanti.

3. Pediatra do Hospital Infantil João Paulo II, Fhemig. Belo Horizonte, Brasil.

Conflict of interests: The authors declare that there is no conflict of interests regarding the publication of this paper. Consent

This study has been approved by the Brazilian Committee of Ethics in Research.
Correspondência

Tadeu Sartini Ferreira. Av. Prof. Mário Werneck, 1685. CEP 30575-180. Belo Horizonte, MG. Brasil. yosartini@hotmail.com

Recebido em 22/04/2015 Aprovado em 05/07/2016 


\section{RESUMO}

Objetivo: Este relato de uma hepatite em um paciente pediátrico pode trazer benefícios para médicos de diversas especialidades, pois ele demonstra um quadro clínico e laboratorial atípicos de uma doença não tão comum nessa faixa etária e que poderia não ter sido diagnosticada.

Descrição do Caso: Uma paciente, de 15 meses de idade, foi referenciada ao hospital com história de 3 dias de febre, vômitos e diarréia. A paciente apresentava alternância entre sonolência e irritação associada com rápida elevação das enzimas hepáticas, mas sem icterícia. Ao exame neurológico não foram evidenciados sinais meníngeos e a tomografia computadorizada de crânio não apresentou alterações. O tratamento consistiu em medicação sintomática junto à avaliação diária dos sinais de encefalopatia hepática ou sangramentos. O painel sorológico foi de IgM negativo e IgG positivo para Citomegalovirus (CMV) e IgM e IgG negativos para Anti-HAV. Em contraste, encontrou-se no soro IgM Imunorreativa contra o antígeno do capsídeo do vírus Epstein-Barr (EBV VCA), o que confirmou um diagnóstico de hepatite pelo EBV. A paciente recebeu alta hospitalar assintomática após 11 dias de internação, com declínio dos valores séricos das transaminases. Um acompanhamento após 15 dias da alta evidenciou completa remissão dos sintomas.

Comentários: O envolvimento do fígado com infecções pelo vírus Epstein-Barr é comum, apresentando elevações moderadas e transitórias das enzimas hepáticas. Ela pode não ser detectada e ser autolimitada, enquanto manifestações hepáticas são infrequentes. Nesse relato de caso, é apresentado um quadro pediátrico atípico de um paciente que desenvolveu hepatite induzido pela infecção por EBV, além de uma revisão na literatura. De acordo com nossa busca, nenhum outro caso de hepatite induzida por EBV foi publicado envolvendo um paciente imunocompetente com idade inferior a 2 anos.

Palavras-chave: Herpesvirus Humano 4. Criança. Hepatite.

\section{Introduction}

Viral hepatitis can be caused by several viruses, including the Epstein-Barr Virus (EBV). ${ }^{1,2}$ EBV is a human herpesvirus (HHV-4) of approximately 120 to $180 \mathrm{~nm}$ in diameter, composed of a doublestranded, linear DNA genome surrounded by a protein capsid. ${ }^{3}$ Its prevalence varies by geographic location, ${ }^{3}$ but it is estimated that more than $90 \%$ of the world population is infected. 4

Infectious mononucleosis (IM) is the most known acute clinical manifestation of EBV infection. ${ }^{5}$ It often begins with malaise and headache, followed by the development of exudative tonsillitis and/or pharyngitis, lymphadenopathy and moderate to high fever. ${ }^{3,5}$ Adolescents and young adults usually present a very typical manifestation, while infection before the age of 10 is commonly asymptomatic or produces an acute illness that is often misdiagnosed. ${ }^{3}$

The majority of patients with IM recover without complications. It is estimated that EBV infection has hepatic involvement in $10 \%$ of young adults and $30 \%$ of the elderly, with varying severity. 5,6 Moderate and transitory increase in liver enzymes is common and can go undetected and resolve spontaneously, while clinical manifestations of hepatitis are infrequent. Jaundice is a rare manifestation, occurring in about $5 \%$ of patients. ${ }^{5,7}$

Hepatitis associated with EBV infection in children has been reported since the 1970s. ${ }^{8}$ However, description of EBV-induced acute hepatitis in infants is scant in the literature. We present a case of an immunocompetent 15-month-old patient with EBVrelated hepatitis which showed atypical clinical manifestations and unusual laboratory findings.

\section{Case report}

A 15-month-old girl presented at the hospital, referred from an emergency care unit, with a 3day history of fever $\left(38.2^{\circ} \mathrm{C}\right)$, vomiting, and diarrhea. On admission, she was noted to be clinically stable, with no signs of dehydration, cyanosis, or jaundice. No alterations on oroscopy, otoscopy, cardiac or respiratory systems were observed. No visceromegaly or lymphadenopathy was found. The patient also showed sensory alterations, alternating between irritation and sleepiness. She did not present 
any meningeal signs. After a neurologic evaluation, a cranial computed tomography was performed which showed no morphological abnormalities.

Laboratory studies performed after the evaluation upon admission yielded hemoglobin: $13.8 \mathrm{~g} /$ $\mathrm{dL}$, hematocrit $43.7 \%$, medium corpuscular volume 79.8fL, medium corpuscular hemoglobin $25.3 \mathrm{~g} / \mathrm{dL}$. The white blood count was 10800 cells with $37 \%$ neutrophils, 3\% band neutrophils and 53\% lymphocytes ( $2 \%$ atypical lymphocytes). Platelet count was 304000 units. The serum levels for potassium, sodium, glucose, C reactive protein, urea, creatinine and venous blood gasometry were within normal range. Serum aspartate transaminase (AST) level was $522 \mathrm{U} / \mathrm{L}$ (normal range, 14-36 U/L), and alanine transaminase (ALT) was $262 \mathrm{U} / \mathrm{L}$ (normal range, 9-52 U/L). The time course of intracellular liver enzymes is shown in Figure1. International Normalized Ratio (INR) was 2.26, prothrombin activity was $34 \%$ and the activated partial thromboplastin time (APTT) was 47.1 seconds (control 33.4s).

Her serum tested negative for IgG [indirect chemiluminescence assay using monoclonal antibodies $^{\mathrm{a}}$ ] and positive for IgM against EpsteinBarr virus viral capsid antigen (EBV VCA) [indirect chemiluminescence assay using monoclonal antibodies $^{\text {b }}$ ]. Cytomegalovirus (CMV) serologic ex- aminations were IgG positive [eletrochemiluminescence, $\mu$-capture assay ${ }^{c}$ ] and IgM negative [eletrochemiluminescence, one-step double antigen sandwich assayd ${ }^{d}$. Anti-HAV tests were negative for both IgM and IgG [eletrochemiluminescence assay using monoclonal antibodies $\left.{ }^{\mathrm{e}}\right]$. The serum was not tested for Hepatits B (HBV) or Hepatits C (HCV).

After the second day, she had no fever, but still presented sporadic vomiting and elevated liver enzymes. She presented with alternation between sleepiness and irritation and was daily evaluated for signs of hepatic encephalopathy or bleeding. For this reason, she was kept in observation even with the remission of other symptoms. On day four, despite the peak in serum liver enzymes levels, the patient had only one episode of vomiting and still alternated between sleepiness and irritation, which only disappeared after day eight of hospital stay. Her treatment regimen consisted of only symptomatic medication. Administration of vitamin $\mathrm{K}$ was not performed due to a progressive decrease of INR. On day 11 after admission, the patient was discharged from the hospital without symptoms, and the parents were advised to return to the hospital in case of adverse events. She returned for a follow-up appointment 15 days after discharge, asymptomatic and with a normal physical examina-

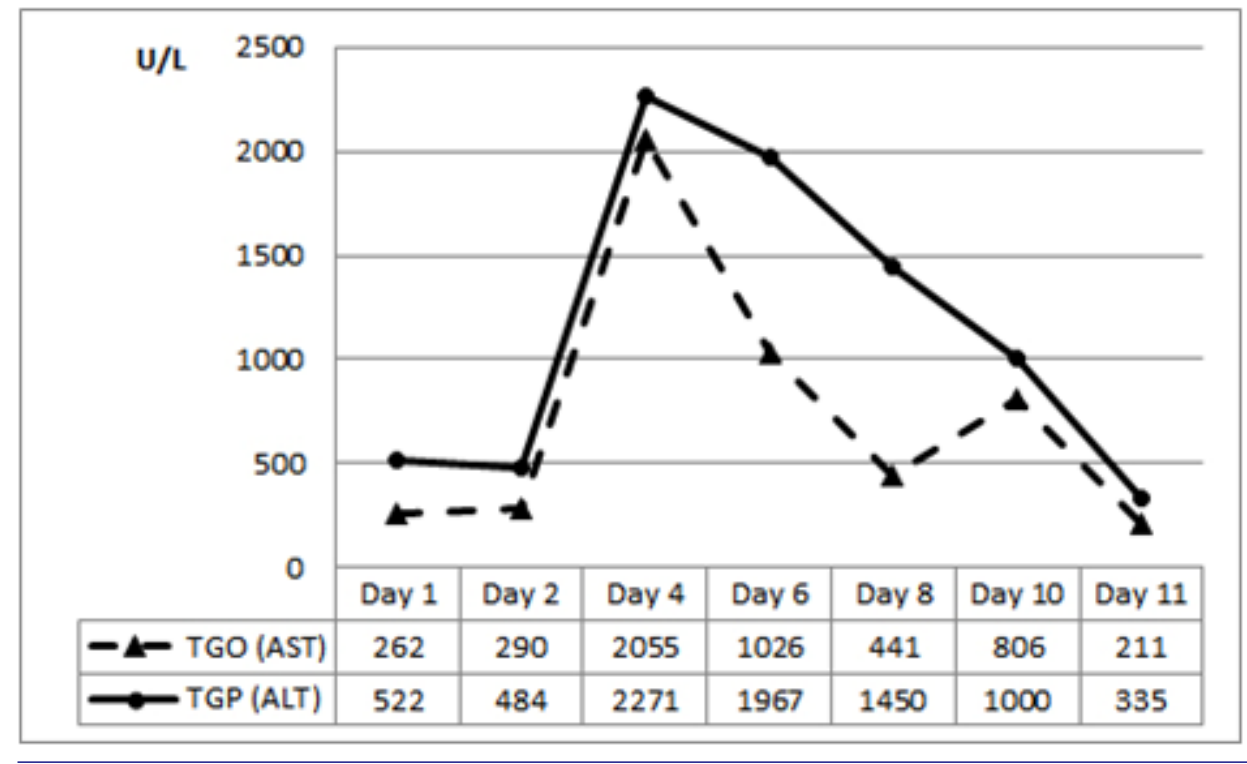

Figure 1: Time course of serum AST and ALT activities during the 11 days period

a DiaSorin LIAISON® EBV IgG Assay.

${ }^{b}$ DiaSorin LIAISON® EBV IgM Assay.
${ }^{\circ}$ Roche Diagnostics Ltda. Elecsys $₫$ CMV IgG Assay.

d Roche Diagnostics Ltda. Elecsys $®$ CMV IgM Assay.

e Roche Diagnostics Ltda. Elecsys ${ }^{\circledR}$ Anti-HAV Assay. 
tion. Liver function tests and complete blood count were normal, but the patient had not done the confirmatory serological tests that were asked.

\section{Discussion}

An electronic search was performed in order to compare this case with others that had already been published about pediatric patients, Articles on EBV hepatitis were identified in the PubMed database using the terms "EBV" or "Epstein" and "hepatitis" on the title. No date-limit was stablished. Other requirements were: case reports and human research. Seventy seven papers were found and manually chosen by abstract analysis.

Limited and inconclusive data about hepatic manifestations of EBV infection are available. ${ }^{7}$ Drebber et al. (2006) proposed that the diagnosis of EBV hepatitis should be based on four parameters: elevated serum levels of AST and ALT, serological EBV activity, demonstration of viral genome by polymerase chain reaction (PCR) or EBV-encoded RNA in-situ hybridization (EBER-RISH) and histopathological changes on liver tissue biopsy. However, these parameters are unreliable if not evaluated together. In our case, a liver biopsy would not benefit the patient, and PCR testing for viral genome was not performed.

The symptoms of acute hepatitis are usually milder and shorter in duration in children when compared to adults. ${ }^{9}$ They are clinically indistinguishable between the viruses and usually consist of vague abdominal pain, vomiting, fever and jaundice. ${ }^{1,9}$ Kofteridis et al. (2011) demonstrated that serum AST and ALT levels started to rise 2 days after the onset of illness and showed peaks, but values did not go higher than 10 times the upper normal limit (360 U/L for AST and $520 \mathrm{U} / \mathrm{L}$ for ALT) after 13 days. His study included 47 patients with documented EBV infection, of median age of 18.5 years and average of 2.9 liver function tests performed per patient. Our patient, however, presented
AST and ALT levels over 45 times the upper normal limit in 4 days, indicating acute hepatocyte injury.

A retrospective study in Korea, 2014, evaluated 36 patients diagnosed with primary EBV hepatitis based on the elevation of ALT levels over $45 \mathrm{U} /$ $L$, early positive EBV IgM (VCA) or early positive EBV IgG (VCA) with positive EBV PCR. It showed that the most common clinical feature was fever, with mean duration of 9 days, followed by cervical lymphadenopathy. The classical triad of IM was seen in about $50 \%$ of the patients. Serum ALT levels over 10 times the upper normal limit were observed in $27 \%$ of the patients and was more common in those with serum alkaline-phosphatase (ALP) and ãglutamyl transferase (GGT) also increased for their age and gender. Serum ALT above 1000 U/L was seen in four patients. ${ }^{10}$ Our patient presented with fever for 4 days, but no signs of lymphadenopathy or tonsillar exudates. She also did not present with hepatomegaly nor splenomegaly. Her ALT levels surpassed the $2000 \mathrm{U} / \mathrm{L}$ mark, but she had no increase of either GGT or ALP. Only 8 out of the 36 patients were under 2 years old and these cases were not reported in greater detail.

Andiman (1976) demonstrated the association of primary infection, with atypical illness in three children in whom he suspected a viral etiology, but hepatitis was only seen in one of them, who was 5 years old. A 17-month-old infant had a nonspecific febrile illness with upper respiratory infection. And a 3-year-old patient presented with fever, hemolytic anemia and adenopathy. According to our search, no other EBV-induced hepatitis cases have been published involving an immunocompetent patient under 2 years of age.

Our patient presented with a lack of the usual clinical manifestations of EBV infection and an unexpected trend in LFTs. Her age and neurological manifestations, which justified a prolonged hospital course, and a lack of other similar reports makes this case unique. 


\section{References}

1. Harvala H, Wong V, Simmonds P, Johannessen I, Ramalingam $\mathrm{S}$. Acute viral hepatitis - should the current screening strategy be modified? J Clin Virol. 2014;59:184-7.

2. Agrawal S, O'Connor $R$, Aoun $E$, Babich $M$. Intense pruritus in Epstein-Barr virus (EBV) hepatitis treated with naloxone drip. BMJ Case Rep. 2015; 2015. pii: bcr2014207037.

3. Odumade OA, Hogquist KA, Balfour Jr HH. Progress and problems in understanding and managing primary EpsteinBarr virus infections. Clin Microbiol Rev. 2011; 24: 193209.

4. Ader F, Chatellier D, Le Berre R, Morand P, Fourrier F. Fulminant Epstein-Barr virus (EBV) hepatitis in a young immunocompetent subject. Med Mal Infect. 2006;36:396-8.

5. Uluð M $^{1}$, Celen MK, Ayaz C, Geyik MF, Hopoðlu S. . Acute hepatitis: a rare complication of Epstein-Barr virus (EBV) infection. J Infect Dev Ctries. 2010;4:668-73.
6. Lawee D. Mild infectious mononucleosis presenting with transient mixed liver disease: case report with a literature review. Can Fam Physician. 2007;53:1314-6.

7. Kofteridis $D P^{1}$, Koulentaki M, Valachis A, Christofaki M, Mazokopakis E, Papazoglou G, Samonis G. Epstein Barr virus hepatitis. Eur J Intern Med. 2011;22:73-6.

8. Andiman WA. Primary Epstein-Barr virus infection and thrombocytopenia during late infancy. J Pediatr. $1976 ; 89: 435-8$

9. Cybulska P, Ni A, Jimenez-Rivera C. Viral hepatitis: retrospective review in a canadian pediatric hospital. ISRN Pediatrics. 2011;2011: Article ID 182964, 4 pages.

10. Yang SI, Geong JH, Kim JY. Clinical characteristics of primary Epstein Barr virus hepatitis with elevation of alkaline phosphatase and gamma-glutamyltransferase in children. Yonsei Med J. 2014; 55: 107-12. 